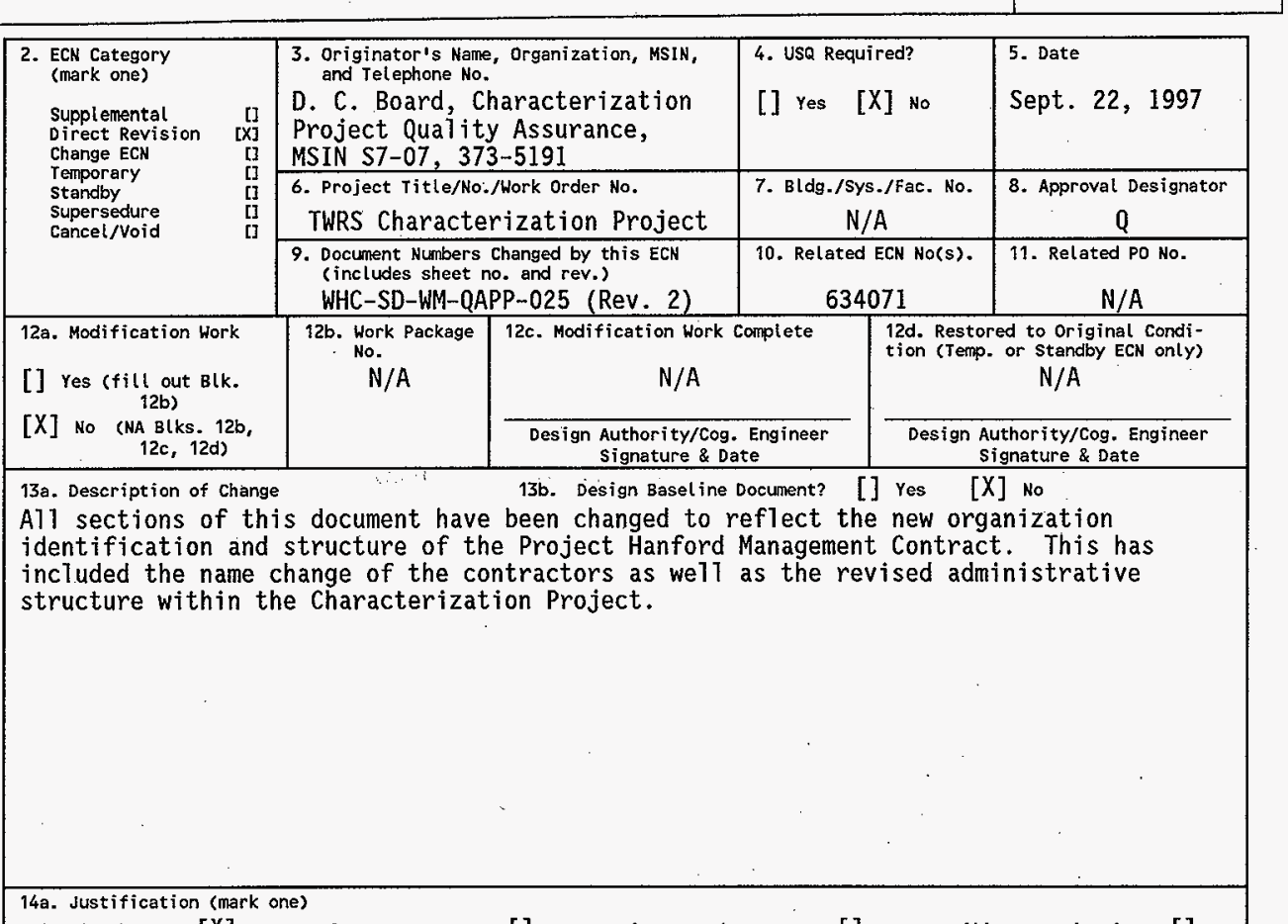

14a. Justification (mark one)

Criteria Change [X] Design Improvement [] Environmental [] Facility Deactivation [] As-Found [] Facilitate Const [] Const. Error/Omission [] Design Error/Omission []

14b. Justification Details

This revision is required to describe quality system changes caused by organizational changes under Fluor Daniel Hanford and to recognize the new names of the performance teams.

15. Distribution (include name, MSIN, and no. of copies)

M. A. Payne \$7-84 1 copy J. G. Kristofzski R2-12 1 copy

C. B. Bryan S7-01 1 copy T. J. Kelley $57-121$ copy

R. J. Cash S7-14 1 copy R. E. Raymond S7-12 1 copy

J. E. Hyatt T6-04 1 copy S. M. Byers S1-57 1 copy

K. D. Haggerty S7-05 1 copy M. R. Adams R2-12 1 copy

J. S. Sparks S7-07 10 copies D. C. Board S7-07 10 copies

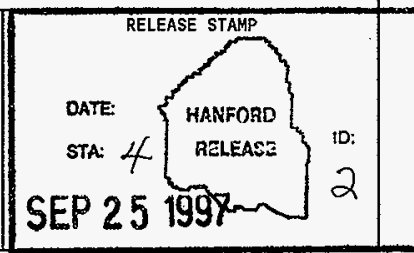




\title{
Tank Waste Remediation System Characterization Project Quality Policies
}

\section{C. Board}

Lockheed Martin Hanford Corporation, Richland, WA 99352

U.S. Department of Energy Contract DE-AC06-96RL13200

\author{
EDT/ECN: 637102 \\ UC: 2070 \\ Org Code: 75000 \\ Charge Code: N4F3A \\ B\&R Code: EW3120074 \\ Total Pages: 60
}

Key Words: CHARACTERIZATION PROJECT QUALITY ASSURANCE, QUALITY POLICIES, QUALITY SYSTEMS, QUALITY CONTROL, QUALITY PLANNING, DATA QUALITY, QUALITY MANAGEMENT SYSTEMS.

Abstract: This quality plan describes the system used by Characterization Project management to achieve quality. This plan is comprised of eleven quality policies which, when taken together, form a management system deployed to achieve quality. This quality management system is based on the customer's quality requirements known as the "RULE", 10 CFR 830.120, Quality Assurance.

IRADEMARK DISCLAIMER. Reference herein to any specific comerciat product, process, or service by trade name, trademark, manufacturer, or otherwise, does not necessarily constitute or imply its endorsement, recommendation, or favoring by the United states Government or any agency thereof or its contractors or subcontractors.

Printed in the United States of America. To obtain copies of this document, contact: Document Control Services, P.0. Box 950, Mailstop H6-08, Richland WA 99352, Phone (509) 372-2420; Fax (509) 376-4989.
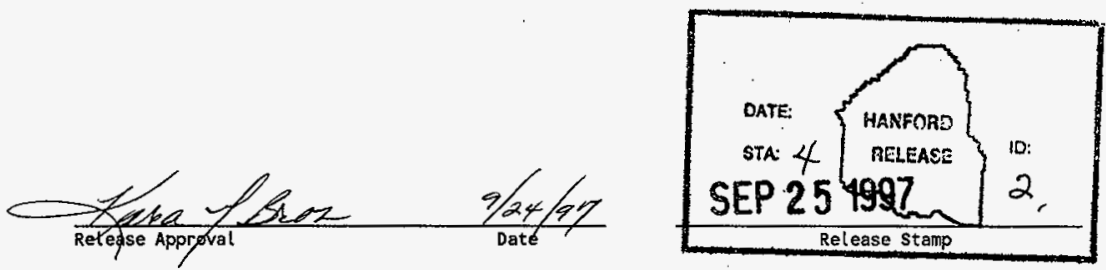


\section{RECORD OF REVISION}

(1) Document Number

HNF-SD-WM-
QAPP-025, Rev 3

(2) Title

Tank Waste Remediation System Characterization Project Quality Policies

September 22, 1997, Revision 3

CHANGE CONTROL RECORD

\begin{tabular}{|c|c|c|c|c|}
\hline \multirow{2}{*}{ (3) } & \multirow{2}{*}{ Revision } & \multirow{2}{*}{ (4) Description of Change - Replace, Add, and Delete Pages } & \multicolumn{2}{|c|}{ Authorized for Release } \\
\hline & & & (5) Cog. Engr. & (6) Cog. Mgr. \\
\hline & 0 & (7) Initial Release (EDT 604268) & & \\
\hline & 1 & Entire revision of document per ECN 704032 & & \\
\hline . & 2 & $\begin{array}{l}\text { 1) Quality Policy } 1.0 \text { is revised to } \\
\text { describe new organization structures and } \\
\text { responsibilities in TWRS, ESQ/QA and also } \\
\text { the Characterization Project. 2) Quality } \\
\text { Policy } 9.0 \text { is revised to describe changes } \\
\text { in management assessments. 3) Quality } \\
\text { Policy } 10.0 \text { is revised to identify the } \\
\text { Facilities Evaluation Board as responsible } \\
\text { for conducting independent assessments. } \\
\text { New Qual ity Policy } 11.0 \text { is added to } \\
\text { describe Data and Information Management } \\
\text { requirements. These changes are being made } \\
\text { as per ECN } 634071 \text {. }\end{array}$ & & \\
\hline & 3 RS & $\begin{array}{l}\text { 1) Al1 pages are changed to reflect the } \\
\text { name changes with the new PHMC. 2) The } \\
\text { organizational structure in Section } 1 \text { is } \\
\text { changed to reflect the most recent } \\
\text { management changes. 3). The document } \\
\text { hierarchy in Section } 1 \text { is changed to } \\
\text { reflect new document names and show the new } \\
\text { Characterization Quality Management Plan. } \\
\text { 4) Editorial text changes were made through } \\
\text { out to reflect changing organizations and } \\
\text { responsibilities without changing the } \\
\text { intent of this plan. Per ECN } 63710 z\end{array}$ & $\begin{array}{l}\text { Aband } \\
9.23 .97\end{array}$ & $\begin{array}{l}\text { オ艹 Byan } \\
9-23-97\end{array}$ \\
\hline & & & & \\
\hline & & & & \\
\hline & & & & \\
\hline & & & & \\
\hline & & & & \\
\hline & & & & \\
\hline & & & & \\
\hline & & & & \\
\hline & & & & \\
\hline & & & & \\
\hline & & & & \\
\hline & & & & \\
\hline
\end{tabular}




\section{HNF-SD-WM-QAPP-025}

Revision 3

\section{Tank Waste Remediation System Characterization Project Quality Policies}

September 22, 1997

Revision 3 
HNF-SD-WM-QAPP-025

Revision 3

Tank Waste Remediation System

Characterization Project

Quality Policies

Lockheed Martin Hanford Corporation Approvals:

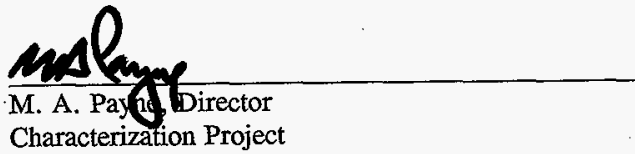

Xtop Pen

S. M. Byers, Manager

Quality Assurance

Approval-1 


\section{HNF-SD-WM-QAPP-025}

Revision 3

This page intentionally left blank.

Approval-2 
HNF-SD-WM-QAPP-025

Revision 3

\section{EXECUTIVE SUMMARY}

\section{E1.0 INTRODUCTION}

\section{E1.1 PURPOSE AND SCOPE}

The Quality Policies (QPs) describe the Quality Management System of the Tank Waste Characterization Project (hereafter referred to as the Characterization Project), Tank Waste Remediation System (TWRS), Lockheed Martin Hanford Corporation.

\section{E1.2 POLICY}

The Quality Policies and quality requirements described herein are binding on all Characterization Project organizations. To achieve quality, the Characterization Project management team shall implement this Characterization Project Quality Management System.

\section{E1.3 CHARACTERIZATION PROJECT DESCRIPTION}

Radioactive waste at the Hanford Site has been generated since 1944 as a by-product of U. S. national defense systems. Liquid radioactive and chemical waste from nuclear materials production was placed initially in underground, reinforced, steel-lined, single-shell tanks (SST), and later in double-shell tanks (DST), for storage.

149 SSTs and 28 DSTs, with capacities ranging from 208,000 to $3,800,000$ Liters $(55,000$ to $1,000,000$ gal.) each, were constructed for high level radioactive waste storage on the Hanford Site. The SSTs contain approximately 137 million L (36.1 million gal.) of waste, consisting of salt cake 88 million L (23.3 million gal.), sludge 46 million L (12.1 million gal.), and supernatant liquids 2.2 million $L$ ( 0.6 million gal.). The waste contains radio nuclides and potentially hazardous nonradioactive substances.

The stakeholders agreed to retrieve and process wastes contained in the SSTs after considering several approaches. Concerns for tank safety and the uncertainty of tank contents led the U. S. Department of Energy (DOE) to enter into agreements to characterize tank wastes. The decision is reflected in the Hanford Federal Facility Agreement and Consent Order (also known as the Tri-Party Agreement) revised strategy (Ecology et al 1994). ${ }^{1}$

${ }^{2}$ Ecology, EPA, and DOE, 1994, Hanford Federal Facility Agreement and Consent Order, as amended, Washington State Department of Ecology, U. S. Environmental Protection Agency, and U. S. Department of Energy, Olympia, Washington. This decision is subject to confirmation in the Tank Waste Remediation System, Environmental Impact Statement. 
The mission of the Characterization Project is to provide information to our customers so they can (1) identify and resolve safety issues to ensure continued safe storage of tank wastes; (2) understand the properties and characteristics of the waste for retrieval, pretreatment, and vendor feed delivery; and (3) achieve the Hanford Site mission objective to dispose of waste stored in Hanford Site SSTs and DSTs.

\section{E1.4 TANK WASTE CHARACTERIZATION PROCESS}

The tank waste characterization process is depicted in Figure E-1.

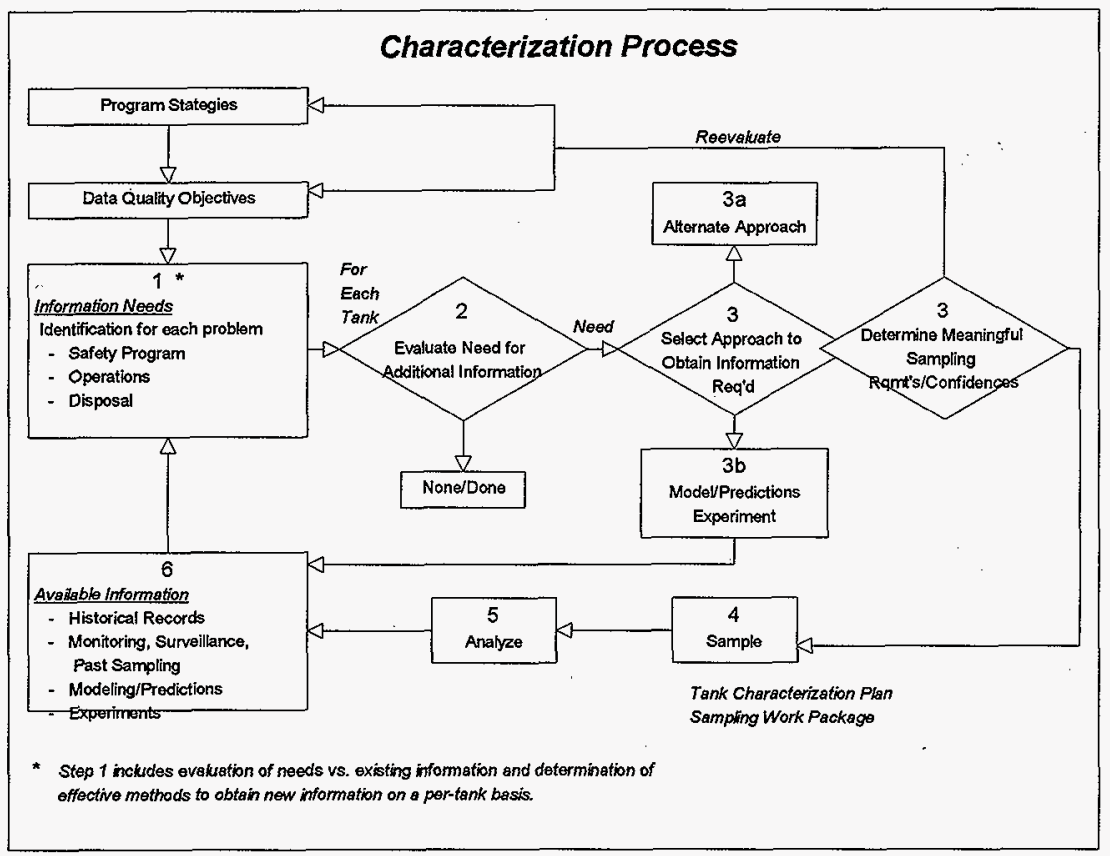

Figure E-1. Tank Waste Characterization Process

The characterization process begins with the need to answer a question or solve a problem concerning the safe storage, pretreatment, or retrieval of tank waste. Those individuals or 
organizations requiring information, or having an interest in the resolution of an issue or problem, are customers of the tank waste characterization process.

Customers employ the data quality objective (DQO) process to determine the information (data) requirements before requesting characterization data that will satisfy information needs. DQOs generated by customers are the primary inputs to the characterization process. DQOs define the type, quantity, and quality of data that customers require. The Process Engineering group, Characterization Project, facilitates the DQO process, and provides information about the types and quality of data that are available, or can be provided. The programs requesting data have final responsibility to define their respective data needs, and drive the development of the DQOs.

Customers "enter" the characterization process with clearly defined information requirements using the outcome from the DQO process. The characterization process determines what information is currently available and what must be obtained through additional effort.

Collection and analysis of new samples is considered if appropriate data is not available. The customer and Characterization Project personnel determine capabilities to collect and analyze new waste tank samples. The DQO defines the data and uncertainty requirements. Using this input, Characterization Project personnel estimate the samples and analyses required to address the customer's problems. Sampling and analyses requirements are provided to the customers to help determine if an approach other than sampling is feasible.

A requirements matrix is developed to determine which requirements apply to each of the waste tanks once the data, sampling, and analysis requirements are determined. This matrix specifies all the data that must be acquired from each tank and helps in establishing priorities based on anticipated data needs. Alternative methods are determined to obtain the needed data. Optimizing data involves evaluating alternatives and determining the best approach for obtaining needed information. The Tank Waste Characterization Basis (Brown, et all.) describes the prioritization process and the outcomes of the prioritization process, and the general plan to obtain the required information from each tank.

Tank characterization plans (TCP) are the instruments used to optimize the sampling and documentation needs for each tank. The TCP integrates differing data needs required to satisfy customer DQO requirements. A tank sampling and analysis plan (TSAP) integral to the TCP specifies the appropriate number of samples and the measurement types required to resolve each customer's issue.

Scheduling of tank sampling is coordinated by Characterization Project Operations (CPO) to achieve priorities and to reduce the number of entries into the same tank.

Collecting and analyzing tank waste samples is a complex and hazardous operation. Consequently, considerable effort is expended in the design, construction, and testing of sampling equipment, apparatus, and analytical procedures needed to safely obtain and analyze 


\section{HNF-SD-WM-QAPP-025}

Revision 3

samples. The development of rotary-mode core sampling equipment and associated analytical methods are examples of this effort.

Some waste tank characterization data are collected in-situ while other problems require the collection and laboratory analysis of physical samples.

CPO collects tank samples using documented methods from the instructions provided by the TCP/SAP, and ships them to qualified laboratories using chain-of-custody procedures.

Samples are received and logged by sample custodians and distributed to trained and qualified analysts using documented analytical methods. Raw, analytical data are generated and verified by performing laboratories. Defensible data packages are assembled, independently validated, and transmitted to Process Engineering Coordinators. Laboratory and other waste tank data are entered into the Tank Characterization Data Base (TCD). Tank characterization reports (TCRs) are written and issued to the customer using standard report formats.

The primary outputs of the tank characterization process are the TCR and TCD. The customer receives the needed information, makes the necessary decision(s), and proceeds to address the waste tank issue or solve the problem. This completes the characterization process.

Details of the characterization process are described in Tank Waste Characterization Process (Dove, et al., 1995), provides an extensive description of this process.

\section{E1.5 CHARACTERIZATION PROCESS QUALITY ASSURANCE AND QUALITY CONTROLS: A GRADED QUALITY APPROACH}

This Characterization Project Quality Management System focuses on the controls and systems necessary to ensure the output quality of the tank characterization process.

The quality controls and systems that Characterization Ptoject management apply to process depend upon the importance of that process to the success of the Characterization Project - a graded approach to quality. 
HNF-SD-WM-QAPP-025

Revision 3

TABLE OF CONTENTS

\section{EXECUTIVE SUMMARY}

E1.0

INTRODUCTION

E1.1

PURPOSE AND SCOPE

E1.2

POLICY

E1.3

CHARACTERIZATION PROJECT DESCRIPTION

E1.4

TANK WASTE CHARACTERIZATION PROCESS

ii

E1.5

CHARACTERIZATION PROCESS QUALITY

iv ASSURANCE AND QUALITY CONTROLS:

A GRADED APPROACH

\section{QUALITY POLICY 1.0}

ORGANIZATION: TWRS CHARACTERIZATION PROJECT RESPONSIBILITY, AUTHORITIES, AND INTERFACES

TWRS Characterization Project

Manager, Characterization Engineering 
HNF-SD-WM-QAPP-025

Revision 3

TABLE OF CONTENTS

\section{QUALITY}

PAGE

1.4

CHARACTERIZATION PROJECT QUALITY

$1-6$

MANAGEMENT SYSTEM DOCUMENTATION

1.4.1

1.4 .2

Quality System Documents

$1-6$

Quality System Basis

$1-7$

1.4 .3

Characterization Project Quality Policies

$1-8$

1.4 .4

Characterization Project Quality Policies Scope

$1-8$

Characterization Project Quality Assurance Project Plans

$1-8$

Procedures, TCPs/SAPs and Work Instructions

$1-9$

1.4 .6

1.4 .7

1.4 .8

Records

$1-9$

Quality Assurance Program Index

CHARACTERIZATION PROJECT QUALITY

MANAGEMENT SYSTEM REVIEWS

1.6

REQUIREMENTS AND RESPONSIBILITIES

Characterization Project Director

Characterization Project Managers

\section{QUALITY POLICY 2.0}

PERSONNEL TRAINING AND QUALIFICATION

PURPOSE AND SCOPE

POLICY

REQUIREMENTS AND RESPONSIBILITIES

Characterization Project Managers

QUALITY POLICY 3.0

QUALITY IMPROVEMENT SYSTEMS and Products 
HNF-SD-WM-QAPP-025

Revision 3

TABLE OF CONTENTS

\section{QUALITY POLICY 4.0}

DOCUMENT AND RECORD CONTROL

Document Control

\section{QUALITY POLICY 5.0}

WORK PROCESS, ITEM AND EQUIPMENT CONTROL

\section{3}

REQUIREMENTS AND RESPONSIBILITIES 
HNF-SD-WM-QAPP-025

Revision 3

TABLE OF CONTENTS

\section{QUALITY POLICY 6.0 \\ DESIGN PROCESS CONTROL}

6.1

PURPOSE AND SCOPE

6-1

6.2

6.2 .1

POLICY

6-1

6.2 .2

Design Standards and Design Reports

6-1

Organizational and Technical Interfaces

6-2

Design Process

6-2

6.2 .3

Design Output

6-2

Design Reviews and Verification

6-2

6.2 .5

Design Changes

6-2

6.2 .7

Design Documentation and Records

6-3

6.3

REQUIREMENTS AND RESPONSIBILITIES

6-3

6.3 .1

Characterization Project Managers

6-3

\section{QUALITY POLICY 7.0}

PROCUREMENT

PURPOSE AND SCOPE

POLICY

Established Specifications $\quad 7-1$

7.2 .1

Supplier Qualifications

$7-1$

Procurement Documents

$7-2$

Supplier Performance Determined from Inspection

and Acceptance Testing

7.2.5

Supplier Performance Determined from Audits

$7-2$

and Assessments

REQUIREMENTS AND RESPONSIBILITIES

$7-2$

Characterization Project Managers

$7-2$

7.3 .2

Characterization Project Quality Assurance

$7-2$

\section{QUALITY POLICY 8.0}

INSPECTION AND ACCEPTANCE TESTING 
HNF-SD-WM-QAPP-025

Revision 3

TABLE OF CONTENTS

QUALITY

PAGE

8.2

POLICY

8-1

8.2 .1

Inspection and Acceptance Testing Planning

8-1

8.2 .2

Measurement and Inspection of Quality Characteristics

$8-1$

8.2 .3

Documents and Records

$8-1$

8.2 .4

Receiving Inspection

$8-2$

8.2 .5

In-Process Measurement, Inspection and Verification

$8-2$

8.2 .6

8.2 .7

Training and Qualification Requirements

$8-2$

Nonconforming Products and Services

$8-2$

8.2 .8

Final Inspection

$8-3$

8.2 .9

Inspection and Testing Equipment

$8-3$

8.3

REQUTREMENTS AND RESPONSIBILITIES

8-3

8.3.1

Characterization Project Managers

$8-3$

\section{QUALITY POLICY 9.0}

MANAGEMENT ASSESSMENTS

\section{1}

PURPOSE AND SCOPE

9.2

POLICY

9-1

9.2 .1

Management Assessment

$9-1$

9.2 .2

Performing Organization

9-1

Assessment Personnel

9-2

Assessment Performance

9-2

Assessment Results and Reports

9-2

9.2 .4

9.3

9.3.1

REQUIREMENTS AND RESPONSIBILITIES

9-2

Characterization Project Directors and Mangers

9-2

Characterization Project Quality Assurance Lead

9-3

QUALITY POLICY 10.0

INDEPENDENT ASSESSMENT

10.1

PURPOSE AND SCOPE

$10-1$

10.2

POLICY

$10-1$

10.2 .1

Assessment Initiated by External Organizations

$10-1$

10.2 .2

Assessment Initiated by Characterization Project

$10-1$ 
HNF-SD-WM-QAPP-025

Revision 3

TABLE OF CONTENTS

QUALITY

POLICY

TITLE

PAGE

10.2 .3

Assessment Results and Reports

$10-1$

10.3

REQUTREMENTS AND RESPONSIBILITIES

$10-2$

10.3 .1

Characterization Project Directors and Managers

$10-2$

QUALITY POLICY 11.0

DATA AND INFORMATION MANAGEMENT

11.1

PURPOSE AND SCOPE

$11-1$

11.2

POLICY

11-1

11.2.1

Data Collection Policy

11-1

11.2 .2

Data Maintenance Policy

$11-1$

11.2 .3

Data Dissemination Policy

$11-1$

11.2.4

Hard Copy and Electronic Policy

11.3

REQUIREMENTS AND RESPONSIBILITIES

$11-2$

11.3.1

Characterization Project Managers

11-2

Technical Lead for Characterization Project Data

$11-2$

Management

REFERENCES

R-1

GLOSSARY

G-1

APPENDIX A

QUALITY ASSURANCE PROGRAM INDEX

A-1 
HNF-SD-WM-QAPP-025

Revision 3

TANK WASTE REMEDIATION SYSTEM

CHARACTERIZATION PROJECT QUALITY POLICIES

\section{QUALITY POLICY 1.0}

\subsection{PURPOSE AND SCOPE}

This policy establishes the Tank Waste Characterization Project's (hereafter referred to as the Characterization Project) requirements, responsibilities, and organization to achieve quality.

\subsection{ORGANIZATION: TWRS CHARACTERIZATION PROJECT RESPONSIBILITY, AUTHORITIES, AND INTERFACES}

Figure 1-1 depicts the Characterization Project organization and management team as part of the Tank Waste Remediation System.

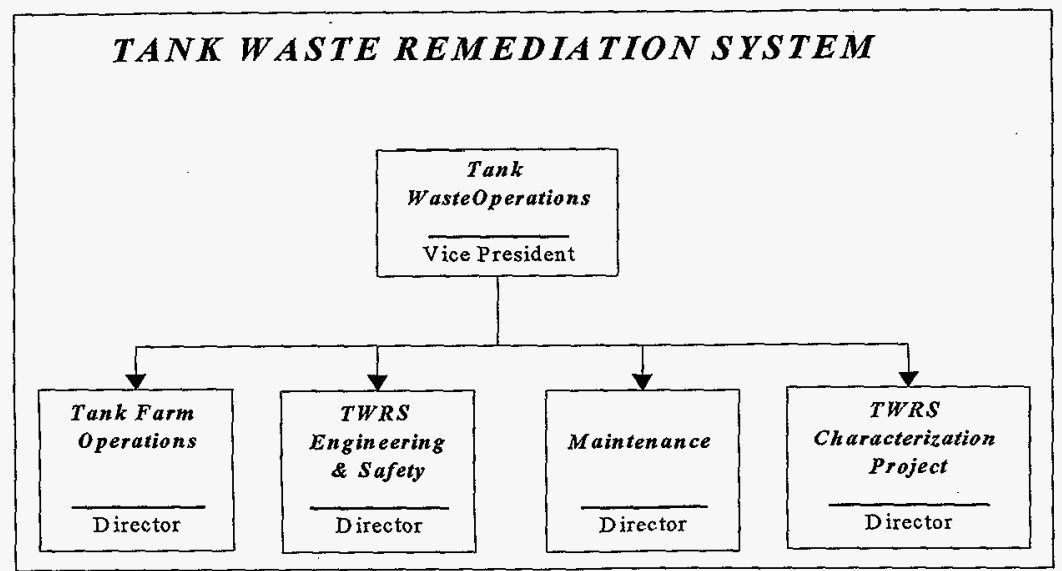

Figure 1-1. Tank Waste Remediation System Organization

\subsubsection{Tank Waste Remediation System (TWRS)}

The TWRS organization is responsible for storing, treating, and immobilizing highly radioactive Hanford Site waste (existing and future tank waste and the Cesium and Strontium capsules) in an environmentally sound, safe, and cost-effective manner. 
The Tank Waste Operations Division is managed by a Vice President who reports directly to the President, Lockheed Martin Hanford Corporation (LMHC) and is charged with the responsibility for safe operations, maintenance, engineering, and characterization of TWRS. The following direct report organizations have been established: Tank Farm Operations, TWRS Engineering \& Safety, Tank Farm Maintenance, and Characterization Project.

Other organizations have been identified to support the Tank Waste Operations Division and are incorporated as matrixed reporting functions to provide the necessary additional technical and administrative functions.

\subsubsection{TWRS Characterization Project}

The TWRS Characterization Project is managed by a Director who reports to the Vice President of the Tank Waste Operations Division.

The responsibility for managing, performing, and assessing the Characterization Project is also separated into direct reporting functions and matrixed functions. The direct reporting functions are "Project Operations" and "Characterization Program." The matrixed functions are Engineering, Process Engineering, Analytical Services, Radiological Control. and Quality Assurance. These organizations are depicted in Figure 1-2.

\subsubsection{Director, Characterization Project}

The Director leads the organization and coordinates the development and implementation of strategic plans. The Director develops the Characterization Project Quality Policies and ensures that the Characterization Project is organized to achieve those policies. The Director ensures that the Characterization Project achieves its policy of continuous process improvement and employee development. In cooperation with the senior management team, the Director develops and implements Characterization Project management systems. In this capacity, the following positions report to the director:

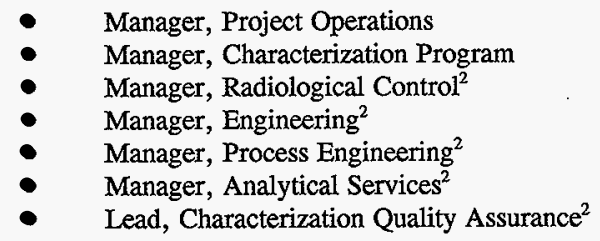

2 This is a matrix assigned responsibility. 
Revision 3

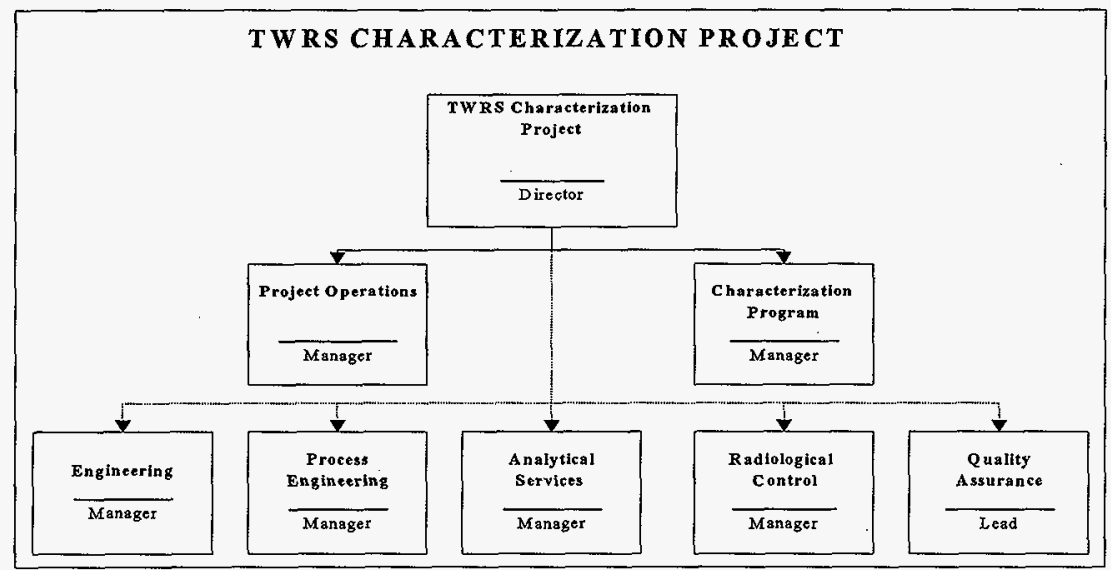

Figure 1-2 TWRS Characterization Project

\subsubsection{Manager, Characterization Project Operations}

The Operations Manager directs tank waste characterization sampling including maintenance, production control, training for Characterization Operations personnel, and those personnel for supporting organizations matrixed to Characterization Operations. The Operations Manager conducts work in a manner that ensures compliance with applicable federal, state, and local environmental regulations.

\subsubsection{Manager, Characterization Program}

The Program manager integrates the efforts of the various Characterization Project organizations by budgeting and tracking funds expenditures, scheduling activities of organizations, resolving issues between organizations, and external activities that involve changes in contracts or relationships. The Program manager communicates with customers and stakeholders by providing commitment status and other periodic reports.

\subsubsection{Manager, Characterization Engineering}

The Engineering manager provides equipment engineering development and sampling support for the Characterization Project. The manager incorporates safety, regulatory compliance, operability, and maintainability into the development of Characterization Project equipment. 
HNF-SD-WM-QAPP-025

Revision 3

\subsubsection{Manager, Process Engineering}

The Process Engineering Manager leads, controls, and monitors the organization that provides the technical leadership and direction for the Characterization Project in support of TWRS tank waste data needs. Process Engineering provides technical direction for collecting and analyzing samples. The Manager guides and directs specialized management teams responsible for interfacing across multiple program boundaries.

Process Engineering is responsible for developing, managing, performing, and assessing the strategies used to characterize tank wastes. Process Engineering assists Characterization Project customers in developing Data Quality Objective (DQO) documents. The customer's DQO establishes the type, quantity, and Quality of data required to address the customer's issue or problem. Process Engineering develops the strategy for prioritizing the tanks to be sampled. Tank Coordinators write Tank Characterization Plans (TCPs) and Tank Sampling and Analysis Plans (TSAPs) used to establish tank sampling and analysis requirements. After waste tank samples have been collected and analyzed, Process Engineering Tank Coordinators compile data into 45 day and other required reports. Besides issuing Tank Characterization Reports, Process Engineering personnel are responsible for maintaining the Tank Characterization Database (TCD).

\subsubsection{Manager, Hanford Analytical Services}

The Hanford Analytical Services Manager leads and directs the handling of samples for distribution to the chemical laboratories doing the work. The Hanford Analytical Services (HAS) team evaluates the resources needed to assure quality analytical results, timely completion of commitments, effective facility utilization, and high customer satisfaction.

The Integrated Contractor Assessment Team (ICAT) within the HAS organization has primary responsibility for assessing the quality systems of each laboratory providing sample analysis services and measurement data to the Characterization Project. Assessments result in the "approval" or "non-approval" of supplier laboratories. Only approved laboratories are "qualified" to provide data to the Characterization Project

\subsubsection{Manager, Characterization Project Radiological Control}

The Manager has the authority to manage monitoring resources to ensure radiological contamination is identified and contained assuring a safe work environment. The Manager will also coordinate Radiological control interfaces within Characterization for training, waste procedure development, waste sampling, sample transport, and maintenance activities.

\subsubsection{Lead, Characterization Quality Assurance}

The Lead Quality Assurance Engineer has direct access to the Characterization Project director and others at the management level where appropriate action can be affected. The Lead has the organizational freedom, authority, and responsibility for ensuring that requirements of the 
Characterization Project Quality Management System are defined, implemented, and maintained.

The QA Lead also has sufficient authority, access to work areas, and organizational freedom to:

- identify and recommend improvement to characterization processes,

- identify and resolve quality problems,

- initiate, recommend, or provide solutions to quality problems,

- verify implementation of corrective action measures and determine that solutions to quality problems are effective (empowered with stop work authority),

- direct assessments, surveillance, inspections, reviews, and audits,

- maintain the characterization Project Quality Management System and Quality Policies.

The Characterization Project QA Lead may delegate authority to quality representatives throughout the TWRS Quality Assurance organization but shall retain overall responsibility. Quality representatives and alternate quality representatives may have other assigned duties within the organization but shall report directly to the Characterization QA Lead for quality matters.

\subsection{CHARACTERIZATION PROJECT QUALITY MANAGEMENT SYSTEM}

The Characterization Project Quality Management System requirements apply to all Characterization Project organizations. The Characterization Project Quality Management System is planned and documented through these Quality Policies and supporting quality documents. The documented quality system will help us ensure that the Characterization Project product conforms to specified requirements.

Activities that affect quality shall be prescribed by these Quality Policies, through quality assurance program plans and quality assurance project plans, plant operating and standard operating procedures, tank characterization plans (TCPs), work packages, work/engineering task plans, sampling and analysis plans (SAPs), and instructions or drawings for the work performed. The quality documents interlock with one another, providing users with an increasing level of detail appropriate for the systems being described.

We shall apply control over quality affecting activities, commensurate with their importance to safety, throughout these quality documents. This is the basis for our graded approach to quality.

The QPs shall be understood, implemented, and maintained at all Characterization Project organizational levels. Characterization Project management, technical, administrative, and support personnel are responsible for implementing the Characterization Project Quality Management System described by these Policies. 
Characterization Project employees shall not deviate from the requirements of the QPs, unless that deviation is approved by the Characterization Project QA Lead or delegated Characterization Project quality assurance personnel.

\subsection{CHARACTERIZATION PROJECT QUALITY MANAGEMENT SYSTEM DOCUMENTATION}

\subsubsection{Quality System Documents}

The Characterization Project quality system is described by the quality documents system. The quality documents system comprises four tiers in increasing level of detail: (1) The Characterization Project Quality Policies; (2) quality assurance project plans or program plans; (3) various procedures, TCPs/SAPs and work instructions; and (4) records. The hierarchy and relationship of higher level quality documents is shown in Figure 1-3.

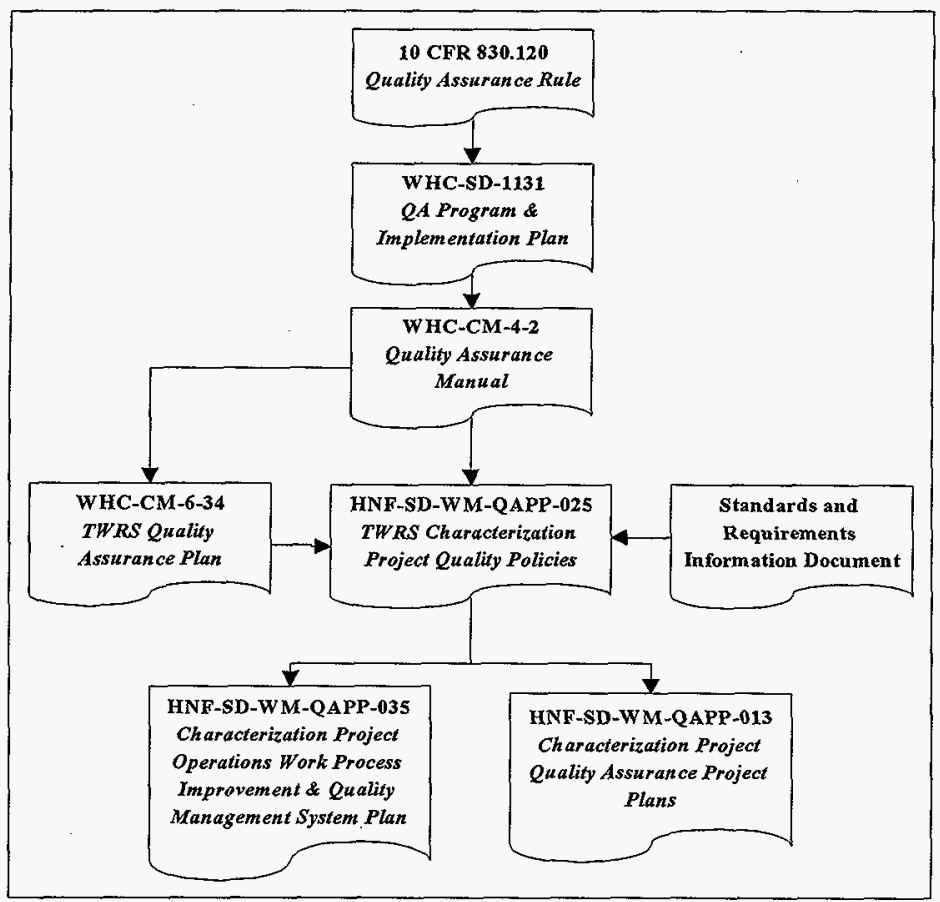

Figure 1-3 Tank Waste Remediation System Characterization Project Quality Documents System 
HNF-SD-WM-QAPP-025

Revision 3

\subsubsection{Quality System Basis}

This Characterization Project Quality Management System is designed to achieve our customer's quality requirements specified in 10 CFR 830.120, "Quality Assurance." Additional customer quality requirements are derived from the Hanford Federal Facility Agreement and Consent Order (Tri-Party Agreement) (Ecology et al. 1994).

The interpretive authority for the customer's quality requirements is the QA Center of Expertise (COE). The QA COE has described the plan to achieve the customer's quality requirements in WHC-SP-1131, Quality Assurance Program and Implementation Plan. WHCCM-4-2, the Quality Assurance Manual, is used at all company levels to implement WHC-SP1131.

Characterization Project Quality Policies are an adjunct to, and consistent with, the Quality Assurance Manual. Additional customer quality guidance originates from EPA QAMS004/80, EPA QAMS-005/80, and EPA QA/G-4, including subsequent amendments or additions to those documents.

The relationship of the customer's quality requirements to the Characterization QPs is shown in Table 1-1.

\begin{tabular}{|c|c|c|}
\hline 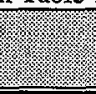 & 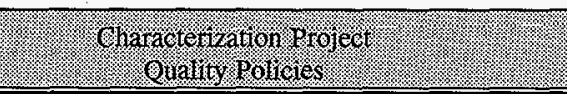 & 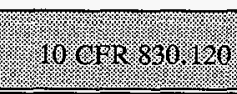 \\
\hline QP 0.1 & Introduction & \\
\hline QP 1.0 & $\begin{array}{l}\text { Management's Quality Policy, Responsibilities, and Quality } \\
\text { System }\end{array}$ & (1)(i) \\
\hline QP 2.0 & Personnel Training and Qualification & (1)(ii) \\
\hline QP 3.0 & Quality Improvement Systems & (1)(iii) \\
\hline QP 4.0 & Document and Record Control & (1)(iv) \\
\hline QP 5.0 & Work Process, Item and Equipment Control & (2)(i) \\
\hline QP 6.0 & Design Process Control & (2)(ii) \\
\hline QP 7.0 & Procurement & (2)(iii) \\
\hline QP 8.0 & Inspection and Acceptance Testing & (2)(iv) \\
\hline QP 9.0 & Management Assessment & (3)(i) \\
\hline QP 10.0 & Independent Assessment & (3)(ii) \\
\hline$Q P 11.0$ & Data and Information Management & \\
\hline
\end{tabular}

Table 1-1. Characterization Project Quality Policies Cross Reference Table. 
Revision 3

Quality is planned through CM-6-34, the TWRS Quality Management Plan. Among other TWRS topics, this document describes the functions, responsibilities, deliverables, and interfaces for the Characterization Project

\subsubsection{Characterization Project Quality Policies}

Lead by the Project Director, the Characterization Project senior management team establishes the Characterization Project quality goals and objectives through this Quality Management Plan. The QPs establish 11 related quality policies based upon guidance of 10 CFR 830.120 to identify Characterization Project quality management. The QPs describe a Quality Management System and what Characterization Project personnel must do to achieve quality.

\subsubsection{Characterization Project Quality Policies Scope}

The scope of the Characterization Project Quality Management System is limited to tank waste characterization and work conducted by organizations of the Characterization Project, and to our suppliers.

\subsubsection{Characterization Project Quality Assurance Project Plans}

Quality Assurance Project Plans describe quality requirements for specific project tasks conducted by Characterization Project organizations or external suppliers (e.g., vapor sampling and analysis, core sampling, laboratory sample analysis, database management, sample archiving, etc.). Quality Assurance Project Plans describe how the Quality Policies are implemented, or employed, for those specific project tasks. QA Project Plans can specify both technical and quality requirements for conducting specific project activities, such as tank vapor sampling and analysis.

Characterization Project Operations maintains a number of Quality Assurance Project Plans (QAPjP) to define controls used in the performance of work. Sampling operations has HNFSD-WM-QAPP-035 Work Process Improvement and Quality Management System Plan. The QAPjP for Vapor analysis is HNF-SD-WM-QAPP-013, Characterization Quality Assurance Project Plan for Sampling and Analysis of Waste Tank Headspace Vapors. Other Characterization Project organizations maintain separate quality assurance project plans appropriate to their specific task. Additionally, requirements to achieve the Characterization Project quality objectives and incoming product quality are described in LMHC approved suppliers' quality assurance project plans, quality assurance program plans, and procurement documents. These must be consistent with Characterization Project management's quality goals and objectives.

Analytical laboratories performing work for the Characterization Project shall be required to develop and implement quality assurance plans responsive to data quality specifications. These plans shall achieve the minimum quality requirements specified in DOE/RL-94-55, Hanford Analytical Services Quality Assurance Plan (HASQAP, RL 1994). If a conflict exists between 
Revision 3

the technical or quality requirements of the HASQAP and Characterization Project requirements, the Characterization Project requirements shall prevail.

\subsubsection{Procedures, TCPs/SAPs and Work Instructions}

Fach organization within the Characterization Project, and external suppliers, shall develop and implement procedures and work instructions for work processes.

TCPs/SAPs are quality documents that provide instructions to field sampling teams and analytical laboratory personnel. TCPs/SAPs typically contain quality requirements for sample collection and laboratory methods.

\subsubsection{Records}

Records form the base of the quality documents system. Records provided documented evidence of achieved quality.

It shall be possible to determine Characterization Project data quality by evaluating appropriate Characterization Project records. We shall identify and maintain records that document conformance of characterization data to our requirements and to our customer's specifications.

\subsubsection{Quality Assurance Program Index}

A Quality Assurance Program Index (QAPI) identifies the implementing procedures required, in part, to achieve these Quality Policies. Implementing procedures are taken mainly from the Quality Assurance Manual and other FDH controlled manuals. The Characterization Project QAPI is shown in Appendix A.

\subsection{CHARACTERIZATION PROJECT QUALITY MANAGEMENT SYSTEM REVIEWS}

The Characterization Project Director and the Director's management team shall review and document the overall effectiveness of its quality management system. System reviews are described in Quality Policy 9.0," Management Assessment."

Independent assessments of the Characterization Project may be conducted by external organizations. The Facilities Evaluation Board (FEB) of Fluor Daniel Hanford Company may conduct assessments from time to time.

The Characterization Project Director and management team shall annually review, revise as appropriate, and approve the Characterization Project Quality Policies. The QPs consists of 11 policies and they may be revised by replacing words within individual policies, or by replacing the entire document. 
Characterization Project managers shall review and approve quality assurance project plans and other quality documents for which they are responsible, as appropriate. Management approval of Characterization Project quality documents signifies a commitment by management to achieve the specified quality requirements.

\subsection{REQUIREMENTS AND RESPONSIBחITIES}

\subsubsection{Characterization Project Director}

The Characterization Project Director:

- Develops, authorizes and releases the Characterization Project Quality Policy statement. The director develops, approves and authorizes the Characterization Project Quality Management System and Quality Policies.

- Assesses and documents the effectiveness of the Characterization Project Quality Management System at least annually.

\subsubsection{Characterization Project Managers}

The Characterization Project managers:

- Approve the Quality Policies concurrent with the Characterization Project Director.

- Implement the Characterization Project Quality Management System, Quality Policies, quality assurance project plans, and supporting quality documents.

- Ensure that the Quality Policies are understood by personnel within the managed organization.

- Develop and implement quality assurance project plans, as appropriate, for the organization managed. Quality assurance project plans shall implement the Quality Policies established by the Characterization Project director.

- Assess, at least annually, the effectiveness of the Characterization Project Quality Management System for the organization managed.

\subsubsection{Characterization Project Quality Assurance Lead}

The Characterization Project Quality Assurance lead:

- Maintains the Characterization Project Quality Management System as described by these Quality Policies.

- Develops, reviews and approves these Quality Policies prior to issuance and at least annually thereafter to incorporate changes and improvements.

- Reviews proposed changes to the Quality Policies.

- Resubmits the revised Quality Policies to the Characterization Project director for approval and authorization. 
HNF-SD-WM-QAPP-025

Revision 3

\section{TANK WASTE REMEDIATION SYSTEM \\ CHARACTERIZATION PROJECT QUALITY POLICIES}

QUALITY POLICY 2.0

PERSONNEL TRAINING AND QUALIFICATION

\subsection{PURPOSE AND SCOPE}

Establish the Characterization Project's policy, requirements, and responsibilities for training and qualifying personnel.

\subsection{POLICY}

We shall train and qualify all personnel whose work processes affect product quality. Training and qualification shall ensure that personnel are capable of performing assigned work, before they attempt that work.

Training and qualification shall ensure that suitable proficiency is achieved initially and maintained thereafter. Training shall be provided to enable employees to adapt to changes in technology, methods, or job responsibilities.

Training and qualification shall be commensurate with the scope, complexity, and nature of the activities performed, and consistent with the education, experience, and proficiency of personnel.

\subsection{REQUIREMENTS AND RESPONSIBILITIES}

\subsubsection{Characterization Project Managers}

The Chacterization Project managers:

- Identify personnel to be trained and qualified.

- Identify specific job tasks that require qualification and commensurate training requirements to achieve qualification.

- Plan and provide personnel training as required.

- Qualify personnel on the basis of education, training, experience or other factors, and ensure that personnel have sufficient technical knowledge to perform assigned work.

- Maintain records of training and qualification.

- Periodically determine training effectiveness; modify training accordingly.

- Establish and maintain procedures, as required, to train and qualify assigned personnel, and to keep records of those processes. 
HNF-SD-WM-QAPP-025

Revision 3

\section{TANK WASTE REMEDIATION SYSTEM \\ CHARACTERIZATION PROJECT QUALITY POLICIES}

QUALITY POLICY 3.0

QUALITY IMPROVEMENT SYSTEMS

\subsection{PURPOSE AND SCOPE}

Establish the Characterization Project's policy, requirements, and responsibilities to prevent conditions adverse to quality, to control nonconforming conditions, to take corrective action(s) when appropriate, and to continuously improve process and product quality.

\subsection{POLICY}

The Characterization Project is comprised of many work processes. Inputs to these processes shall meet our established requirements to assure product quality, When inputs do not meet these requirements, nonconforming items or services shall be controlled to prevent their inadvertent use.

We shall establish quality controls for critical process characteristics, and those characteristics shall be monitored to ensure that processes meet our specifications. If problems occur, we shall take corrective action(s), as appropriate, to permanently remove those problems.

We shall monitor process outputs so that we can identify nonconforming products. We shall use various systems to measure the performance of our processes and we shall focus our efforts on process improvement to prevent quality failures. Defect detection and correction are important, but not optimal methods to assure quality.

\subsubsection{Control of Nonconforming Items, Services, Processes, and Products}

We shall specify appropriate quality requirements and control purchased items, services, and finished products that do not conform to those specified requirements. We shall prevent inadvertent use of nonconforming products in the characterization process, and the release of nonconforming data to the customer.

We shall identify, document, segregate when practical, report, evaluate, and disposition nonconforming items and products:

We shall continuously evaluate our work processes to ensure conformance with process specifications. Appropriate action shall be taken to prevent process failures. In the event that 


\section{HNF-SD-WM-QAPP-025}

Revision 3

processes produce defective product, those work processes shall be stopped and appropriate action(s) taken to prevent recurrence.

We shall notify those organizations that are affected by nonconforming items, services and products. The Nonconformance Report shall be used to record, report, and document nonconformances, and to disposition nonconformances and descriptions of rework or repair to items, services, and products that do not conform to specifications.

All Characterization Project and subcontractor personnel shall have sufficient freedom and authority to identify nonconforming items, services and products.

\subsubsection{Corrective Action}

The cause for recurring nonconformances, or nonconformances which have a significant negative impact on quality, shall be determined and permanently removed from processes through corrective action(s). We shall determine causes before preventive measures are planned and implemented.

We shall put in place controls to ensure that conditions adverse to quality are promptly identified and that effective corrective action(s) is taken.

The resources that we expend to permanently eliminate nonconformances, shall be commensurate with the significance of the problem.

All Characterization Project and subcontractor personnel shall have sufficient freedom and authority to identify nonconforming items and processes, identify and suggest improvements to work processes, and take corrective action(s), as appropriate.

\subsubsection{Process Improvement and Problem Prevention}

We shall collect and analyze data from nonconformance reports, corrective action(s), assessments and other process, item, and service quality measurements, as appropriate. Our objective is to quantify performance limitations and determine which processes need improvement.

As an aid to predicting and preventing quality problems before they occur, we shall conduct trend analysis.

Employees at all organizational levels shall participate in quality improvement, either individually or in teams, to improve process or product quality. 
HNF-SD-WM-QAPP-025

Revision 3

\subsection{REQUIREMENTS AND RESPONSIBLITIES}

\subsubsection{Characterization Project Managers}

The Characterization Project managers:

- Establish a culture and work environment that encourages employees to improve processes and product quality. Provide the systems, framework, motivation, resources, and time for employees to improve process and product quality.

- Train assigned employees in the areas of identifying nonconforming items and services and completing corrective action(s).

- Detect and disposition nonconformances. Ensure that nonconformances which significantly impair quality or which recur are permanently corrected.

- Measure, gather, and analyze appropriate information and data to determine whether product and service quality is improving. Take action before quality problems occur.

\subsubsection{Characterization Project Employees}

All Characterization Project employees have the freedom, authority, and responsibility to identify, document, segregate, and report nonconforming items, products, or services. Engineering personnel are primarily responsible to evaluate and develop the disposition of nonconforming materials.

All Characterization Project employees have the freedom, authority, and responsibility to improve work processes and to take corrective action(s) when required.

\subsubsection{Characterization Project Quality Assurance (QA)}

Characterization Project QA shall assist Characterization Project personnel by logging and tracking Nonconformance Reports issued by, or for the Characterization Project. 
HNF-SD-WM-QAPP-025

Revision 3

\author{
TANK WASTE REMEDIATION SYSTEM \\ CHARACTERIZATION PROJECT QUALITY POLICIES
}

\author{
QUALITY POLICY 4.0 \\ DOCUMENT AND RECORD CONTROL
}

\title{
4.1 PURPOSE AND SCOPE
}

Establish the Characterization Project's policy, requirements, and responsibilities to control documents and records of quality affecting activities.

\subsection{POLICY}

We shall write down our quality policies, plans and requirements, and those procedures needed to implement those policies, plans and requirements. These documents form the written basis of our quality system. Our purpose is to communicate our quality objectives to everyone in the Characterization Project organization. We shall also provide our suppliers with documents specifying requirements for procured products and services, so they understand what quality we require from them.

We shall specify and control records that provide evidence of achieved quality as required by our customer. We shall also require our suppliers to maintain and control specific records that document product quality for those items and services that are critical to our processes.

\subsubsection{Document Control}

Documents are used to plan and control systems, projects and work. Documents are written at three levels of the Quality System: 1) Quality Policies; 2) Quality assurance program and project plans; and 3) Work instructions and procedures.

Records, which can be considered a fourth level of the quality documents system, are generated as an outcome of conducting work processes. Records are retained to provide proof of achieved quality.

Characterization Project divisions, departments, and projects shall ensure that our quality system documents (Quality Policies, quality assurance program plans, quality assurance project plans, SOPs, POPs, TCPs/SAPs, work instructions, design documents, procurement documents) are reviewed for adequacy, approved for release by authorized personnel, and distributed to and used at the location where the work is being performed.

Characterization Project document reviewers and approvers shall have access to pertinent background information on which to base their reviews. 
Changes, other than minor changes, to Characterization Project Quality Management System documents shall be reviewed and approved by the same organization that performed the original review and approval, unless specifically designated otherwise.

\subsubsection{Records and Documentation}

We shall document and keep records of Characterization Project activities that affect quality. These records shall demonstrate to ourselves and to our customer that, for example, Characterization Project employees have received proper training, correct procedures are in place where work is being performed, sampling and analysis processes are in control, and purchased items and services meet specified requirements.

We shall maintain appropriate subcontractor documentation as part of the Characterization Project's records because we use subcontractors to design and fabricate sampling equipment, conduct chemical analyses, write quality documents, and conduct other work needed to characterize tank waste,

Records that we retain to document quality shall be legible, accurate, dated (including revision dates), clean, readily identifiable to the product or service involved, complete, and maintained in an orderly manner. Records and documentation may be stored via hard copy, or electronically or magnetically, but they must be readily retrievable.

We shall identify (list), specify, prepare, and maintain records that provide documentary evidence of achieved quality.

We shall protect those records against tampering, damage, deterioration, or loss.

When we develop or write design specifications, procurement documents, test procedures, and operational procedures, they shall specify the records to be generated, supplied, or maintained as a result of those activities.

\subsection{REQUIREMENTS AND RESPONSIBILITIES}

\subsubsection{Characterization Project Director}

The Characterization Project director is responsible for developing, authorizing and releasing the Characterization Project Quality Policy statement.

The Characterization Project director develops, approves and authorizes the Characterization Project Quality Management System as described by the Quality Policies. 
HNF-SD-WM-QAPP-025

Revision 3

\subsubsection{Characterization Project Managers}

Characterization Project managers:

- Develop and approve the Characterization Project Quality Policies.

- Develop, prepare, approve and authorize the release of quality assurance program plans, quality assurance project plans, laboratory quality assurance plans, standard operating procedures, plant operating procedures, and work instructions, for the organization managed,

- Control Characterization Project Quality Management System documents according to approved document control procedures for the organization managed,

- Identify and authorize personnel who prepare, review, and issue original or changed documents and ensure that documents are reviewed for adequacy, completeness, and correctness prior to approval and issuance.

- Ensure that pertinent issues of appropriate documents are available at all locations where the prescribed work process is performed.

- Identify Quality documents and records which will be collected, indexed, filed, stored, maintained, and dispositioned as specified by appropriate quality assurance project plans, quality assurance program plans, or other documents.

\subsubsection{Characterization Project QA}

The Characterization Project QA lead is responsible for developing, reviewing for adequacy, approving, maintaining, controlling and releasing the Quality Policies.

\subsubsection{Authorized Copyholders of Quality Documents}

All copyholders of quality documents are responsible for updating their assigned documents by removing obsolete material and inserting current material. 
HNF-SD-WM-QAPP-025

Revision 3

\author{
TANK WASTE REMEDIATION SYSTEM \\ CHARACTERIZATION PROJECT QUALITY POLICIES
}

\author{
QUALITY POLICY 5.0
}

WORK PROCESS, ITEM AND EQUIPMENT CONTROL

\title{
5.1 PURPOSE AND SCOPE
}

Establish the Characterization Project's policy, requirements, and responsibilities to control work processes, equipment and critical process inputs that affect the quality of our services and products.

\subsection{POLICY}

All work is accomplished by a process. A process is a value-added transformation involving people and other resources. The outputs are the results of the process. Characterizing tank waste is a network of processes, the outcome of which is characterization data reported to customers and to the Tank Characterization Database.

Critical inputs to characterization processes shall be specified and controlled in order to meet our customer's quality requirements for tank waste characterization data that it is technically valid and defensible. Inputs to the characterization process (see Figure E-1) are personnel (training and knowledge), equipment, procedures, work environment, supplies, samples, and performance specifications and technical requirements (e.g., DQOs).

We shall design, conduct, monitor and control work processes to produce outputs which conform to established specifications. Work processes shall be performed in a suitable work environment using suitable equipment.

\subsubsection{Administrative Controls and Technical Standards}

Work processes that we use to characterize waste shall be performed to established, and currently accepted, technical standards and to adequate administrative controls and documented procedures.

\subsubsection{Use of Instructions and Procedures}

We shall conduct processes which directly affect quality under controlled conditions using approved instructions, procedures, checklists, travelers, drawings, or other appropriate means. 
We shall write procedures and instructions at a level and detail appropriate for the importance and complexity of the work process being performed so they will be understood and used.

Procedures and work instructions shall be readily available for use where the activity described by those instructions is performed.

\subsubsection{Identification and Control of Items}

Incoming products, materials, and items that are critical to the success of Characterization Project work processes shall conform to specified requirements.

We shall identify the status of incoming critical process items to indicate that those items conform to established requirements. We shall maintain records which document that conformance.

We shall establish the identity of critical inputs to the tank waste characterization process so that we can trace those inputs back to their source, if necessary. Purchase documents for critical process items shall be retained in our project records.

We shall assign each sample a permanent number that is traceable throughout the handling, analysis, data reporting, data storage, and sample archiving processes when we collect tank characterization samples, To ensure sample traceability and integrity, standardized Chain-ofCustody forms shall be completed by field personnel whenever samples are collected or transferred.

We shall keep records identifying critical process equipment used to collect samples, or to make measurements in the field, or to analyze samples of tank waste or vapors in the laboratory: If problems arise, we can determine which samples or data may be affected by equipment problems.

We shall record the names of personnel who perform or verify critical characterization process work because we must be certain that characterization processes are conducted by properly trained and qualified personnel,

We shall record the results of quality control protocols used to verify sampling and test methods in order to demonstrate that processes are in control during sampling and analysis, This quality control data shall be traceable to specific tank samples and analysis reports. Our quality control and records systems shall enable us to trace tank sampling events and analytical reports to the people doing the work, the methods that were used to collect and analyze the samples, and to demonstrate that those processes were in control at the time of sample collection and analysis. 


\section{HNF-SD-WM-QAPP-025 \\ Revision 3}

\subsubsection{Maintenance and Preservation of Items}

We shall implement controls to verify, store, and maintain tank characterization samples and other environmentally sensitive materials. These controls shall ensure that samples, or other items, and their associated documents and records, will be protected against deterioration, loss, damage, or other events that would render the materials unsuitable for use. We shall maintain this protection during the collection, storage, handling, preparation, analysis, and archiving of tank characterization samples.

Performing laboratories shall be maintained as secured areas at all times to ensure the defensibility of characterization data, implement chain-of-custody procedures, and maintain the integrity of tank waste samples,. These laboratories will limit access to only authorized personnel and registered, accompanied visitors.

We shall maintain, monitor, and document those conditions when an item or sample must be stored under specific environmental conditions (e.g., refrigerated), When a sample, test item, or associated document is to be held secure, storage and security arrangements shall be provided to protect the conditions and integrity of the secured items. Sampling media and tank waste samples and test items shall be maintained in a manner to minimize accidental or unintentional alteration.

We shall develop controls to ensure that unsuitable damaged or deteriorated items are not used. When a tank waste sample, test item, or other material is lost, damaged, or otherwise becomes unsuitable for use, that event shall be reported to the appropriate Characterization Project customer and recorded using the appropriate records or forms.

Laboratories that we use to conduct analyses of tank waste samples shall properly receive, document, and record the arrival of sampling media. Items and samples to be tested shall be uniquely identified upon receipt through documented log-in procedures. It is our policy that all performing laboratories shall accept custody of tank characterization samples, verify submitted information, and make the appropriate entries on standardized Chain-of-Custody forms and other records. If there are any abnormalities, departures, or nonconformances from standard conditions, the performing laboratories shall record that information upon receipt of samples and notify appropriate personnel.

Laboratories that we use to analyze Characterization Project samples are required to have, and use, documented procedures for receiving, retaining, and archiving Characterization Project samples. 


\subsubsection{Calibration and Maintenance of Equipment}

Devices and equipment used during the collection, analysis, measurement, testing, and reporting of tank waste samples usually require periodic calibration and maintenance.

We shall control, uniquely identify, calibrate and maintain the equipment used in sampling and analysis processes in order to assure the validity of Characterization Project samples and data, We shall use this equipment in a manner that ensures that measurement uncertainty is known and consistent with the required measurement capability. We shall select and use equipment that is of the correct type, and that has the proper range, accuracy, and tolerance for its intended purpose.

The method and interval of calibration for each measuring and test equipment based on the type of equipment, stability characteristics, required accuracy, intended use, and other conditions affecting measurement control shall be specified. We shall calibrate our measuring and test equipment prior to use or at prescribed intervals that conform to sampling, analytical, test method, or calibration procedures, and whenever the accuracy of measuring and test equipment is suspect.

The Characterization Project and subcontractor's calibration and verification systems shall be traceable to national standards of measurement, when available. When traceability to national standards does not exist, we shall document satisfactory evidence of correlation of results for calibration.

We shall identify measuring and test equipment by use of a suitable indicator or approved identification record to show current calibration status except for measuring and test equipment that requires calibration or calibration verification prior to each use (e.g., emission spectrometers, mass spectrometers, etc.), Whenever any equipment requiring calibration is determined to be out of calibration, previous results shall be evaluated to determine the validity of previously accepted tests or measurements.

Field, laboratory, and other equipment used in the characterization process shall be provided with periodic and routine preventive maintenance to prevent process and quality failures. Maintenance shall be conducted in accordance with manufactures', or other suitable recommendations. We shall maintain appropriate records of equipment maintenance to document acceptable operating conditions.

We shall tag or segregate defective or out-of-calibration equipment and devices, or equipment subjected to mishandling, and not use them until they have been recalibrated and verified as suitable. Equipment that is found to be consistently out-of-calibration shall be repaired or replaced. 
HNF-SD-WM-QAPP-025

Revision 3

\subsection{REQUIREMENTS AND RESPONSIBILITIES}

\subsubsection{Characterization Project Managers}

The Characterization Project managers:

- Identify, develop, verify, assess, approve, maintain, and control appropriate quality documents in order to implement these Quality Policies and to control work processes.

- Ensure that personnel are provided with necessary training, suitable equipment, suitable working environment, and administrative controls to accomplish work processes.

- Monitor processes that affect quality to ensure that specified requirements are met and processes conform to documented procedures.

- Review and assess work and related information to ensure that the required quality is being achieved and to identify processes that require improvement.

- Establish and implement processes to identify, control, and maintain critical items, and to control supplies and items that have a limited shelf life. Identify items, samples, and materials that are held in storage in a manner that is consistent with the planned duration and conditions of storage.

- Provide the necessary equipment and administrative controls to collect, transport, receive, store, secure, analyze, and maintain tank characterization samples and materials according to Characterization Project requirements, customer requirements, and regulatory requirements.

- Ensure the identification and traceability of the following: tank characterization sampling media, samples and testing materials, critical process input materials, equipment calibration and calibration standards, personnel performing and verifying measurements, measuring equipment, quality control and verification data, test methods, analytical reports, and test results.

- Provide employees with the equipment required for the correct performance of test procedures and measurements. Ensure that measuring and test equipment is capable of the precision and bias (accuracy) for those measurements and tests.

- Develop, implement, and maintain a documented system for calibration and verification of measuring and test equipment used in the characterization process. 


\section{HNF-SD-WM-QAPP-025}

Revision 3

- Develop and maintain current lists or other records identifying each measuring and test device by name; type; serial or identification number; date and condition when received; manufacturer's instructions; service date; location, description, or method of calibration; acceptance criteria; action to be taken when results are not satisfactory; frequency of calibration required; and date of last calibration and date when next calibration is required.

- Ensure that measuring and test equipment is maintained according to documented procedures and that maintenance records are maintained, including records of any damage, malfunction, modification, or repair.

- Maintain calibration records of measuring and test equipment.

- Ensure that all procedures, instructions, manuals, and reference data are current and available to Characterization Project personnel at the site of sampling, test and measurement activities.

\subsubsection{Characterization Project Employees}

Characterization Project employees:

- Understand the requirements of the work performed and the capability of the equipment, systems, and processes used.

- Accept responsibility for achieving the requirements of work performed.

- Follow approved procedures and processes.

- Report to appropriate management those processes which do not conform with the Characterization Project's specifications or the customer's specifications, or which can be improved to reduce costs or improve quality.

- Maintain the care and custody of the customer's samples and materials during the collection, receipt, storage, analysis, disposal, or return of those samples and materials.

- Safeguard measuring and test equipment hardware and software from adjustments which would invalidate calibration settings. 
HNF-SD-WM-QAPP-025

Revision 3

\title{
TANK WASTE REMEDIATION SYSTEM \\ CHARACTERIZATION PROJECT QUALITY POLICIES
}

\author{
QUALITY POLICY 6.0
}

DESIGN PROCESS CONTROL

\subsection{PURPOSE AND SCOPE}

Establish the Characterization Project's policy, requirements, and responsibilities to control and verify tank characterization sampling designs and equipment engineering designs.

\subsection{POLICY}

Sampling systems, sampling plans, and sampling equipment must be designed in order to characterize tank wastes. To minimize rework, prevent failures and the collection of unneeded or unsuitable samples or data, and to ensure that specified requirements are met, we shall control the design of these systems, items and plans.

\subsubsection{Design Standards and Design Inputs}

When we design tank sampling or other equipment, or tank characterization sampling plans, we shall use correct standards and engineering/scientific principles. Applicable design bases and requirements shall be identified, documented, and incorporated into our designs.

Customers must use the U.S. Environmental Protection Agency (EPA) Data Quality Objective process, or equivalent, to determine and specify tank characterization data requirements to prevent the collection or analysis of unnecessary tank waste samples,

The EPA Data Quality Objective process, as applied to characterizing tank wastes, is described in EP-0732, TWRS Data Quality Objective Strategy. This document describes how to develop and transform a statement of stakeholder problems/issues into a design which specifies the type, quantity and quality of characterization data required. Additional tank characterization design inputs can be developed using SD-WM-TA-164, Tank Waste Characterization Basis.

The Characterization Project requires the completion of the DQO process by the customer to ensure that client requirements are adequately defined and documented. The DQO process provides the necessary interface betwieen the Characterization Project and the customer to resolve differences between capabilities and data requirements. The DQO is the prerequisite to entry into the characterization process. 


\section{HNF-SD-WM-QAPP-025}

\section{Revision 3}

\subsubsection{Organizational and Technical Interfaces}

When we design equipment or sampling processes, the appropriate personnel shall participate in the design. We shall maintain effective communication and appropriate levels of involvement with affected personnel throughout the design process.

When we send information about designs to other people or organizations, we shall keep records of those transmittals. These transmittals shall identify what we are sending, its status, and what needs to be done with the transmitted information.

\subsubsection{Design Process}

When we develop a design, we shall identify those processes, components and structures which are critical to the quality, reliability or safety of the designed system. TCPs and sampling and analysis plans shall be based upon the customer's requirements for the type, quantity and quality of information required.

\subsubsection{Design Output}

When we complete the design of an item or system, or a plan to collect and analyze tank waste samples, we shall produce a suitable document to record that design. Design documents include drawings, specifications, Tank Characterization Plans, sampling and analysis plans and test/inspection plans.

\subsubsection{Design Reviews and Verification}

We shall verify our designs to ensure that they meet established requirements and the requirements of their intended customer. Designs shall be evaluated by analysis against customer requirements, comparisons with similar proven designs (if available), use of alternate calculations, performance of qualification tests, and other competitive or benchmark standards.

Characterization Project personnel who review and verify designs shall be qualified to do so; they shall be different from personnel who complete the original design.

We shall verify, validate and approve our designs before tank characterization samples are collected, equipment fabricated, or designs implemented,

\subsubsection{Design Changes}

We shall assure the validity of a new design, considering how the proposed change will affect the original structure, system, or component. When we propose a change to an approved design, we shall subject those proposed changes to commensurate controls that were applied to the original design. 


\section{HNF-SD-WM-QAPP-025}

\section{Revision 3}

\subsubsection{Design Documentation and Records}

We shall generate, collect, store and maintain design documentation and records, which provide evidence that the design and design verification processes were performed according to our and to our customer's requirements.

\subsection{REQUIREMENTS AND RESPONSIBILITIES}

\subsubsection{Characterization Project Managers}

Characterization Project managers:

- Ensure that Characterization Project engineering and sampling and analysis designs are defined, controlled, and verified.

- Ensure that applicable design inputs are appropriately specified in a timely manner and correctly translated into design documents.

- Identify and control design interfaces.

- Verify adequacy of design.

- Control design changes in a manner commensurate with the control of the original design. 
HNF-SD-WM-QAPP-025

Revision 3

\title{
TANK WASTE REMEDIATION SYSTEM CHARACTERIZATION PROJECT QUALITY POLICIES
}

\author{
QUALITY POLICY 7.0
}

PROCUREMENT

\subsection{PURPOSE AND SCOPE}

Establish the Characterization Project's policy, requirements, and responsibilities for ensuring that purchased items and services conform to established requirements and perform as specified.

\subsection{POLICY}

We shall identify and control quality affecting inputs to the characterization process that are purchased from external suppliers.

We shall control purchased process inputs to assure process output quality, The extent of control that we apply shall depend on how important that product or service is to the success of the characterization process output. "Controlled" is defined as: (1) establish the proper requirements for the service or product that we need, (2) select vendors that can always meet our requirements, and (3) confirm that suppliers did, in fact, provide the quality that we specified, initially and thereafter.

\subsubsection{Established Specifications}

We shall first establish appropriate specifications for items and services in order to obtain quality. We define quality as conformance to our established requirements. We shall establish and maintain specifications for critical services and materials that we purchase.

\subsubsection{Supplier Qualifications}

We shall select suppliers of critical items and services on the basis of their ability to meet our requirements, including quality characteristics for the items and services that we purchase. But we shall also evaluate suppliers on their ability to continuously meet our quality system requirements, because we must always purchase defect-free products.

We shall establish and maintain records or lists of suppliers that can meet and exceed our specifications and quality requirements. The extent of a supplier's quality system that we require, shall depend on the type and use of the item or service being purchased. 
HNF-SD-WM-QAPP-025

Revision 3

We shall qualify suppliers on the basis of one or more of the following criteria:

- Type of product supplied

- Onsite assessment

- Examination of product samples, or product test results

- Past performance for identical or similar items/services

- Demonstrated capability or documented experience of users

- Vendor-supplied product data

- Objective evidence of quality supplied by vendors.

\subsubsection{Procurement Documents}

We shall use standardized procurement documents when we purchase an item or service, The documents shall clearly define the specified technical requirements to communicate the required quality of the purchased item, product, or service.

\subsubsection{Supplier Performance Determined from Inspection and Acceptance Testing}

Procurement documents shall identify any tests, inspection, or acceptance requirements for monitoring and evaluating the supplier's performance initially and thereafter.

\subsubsection{Supplier Performance Determined from Audits and Assessments}

Procurement documents shall provide for access to the suppliers' facilities and records for inspections or audits by Characterization Project personnel, or designated representatives.

\subsection{REQUIREMENTS AND RESPONSIBILITIES}

\subsubsection{Characterization Project Managers}

Characterization Project managers:

- Identify critical products and services that will be obtained through procurement services. Provide that information to procurement services.

\subsubsection{Characterization Project Quality Assurance}

Characterization Project Quality Assurance:

- Assists in supplier reviews, audits, and assessments, as necessary.

- Maintains records of supplier reviews, audits, and assessments conducted by Characterization Project quality representatives. 
HNF-SD-WM-QAPP-025

Revision 3

\author{
TANK WASTE REMEDIATION SYSTEM \\ CHARACTERIZATION PROJECT QUALITY POLICIES
}

\author{
QUALITY POLICY 8.0
}

\title{
INSPECTION AND ACCEPTANCE TESTING
}

\subsection{PURPOSE AND SCOPE}

Establish the Characterization Project's policy, requirements, and responsibilities for inspection and testing of incoming, in-process, and finished items, services and processes and documenting the results of those verifications.

\subsection{POLICY}

\subsubsection{Inspection and Acceptance Testing Planning}

We shall plan inspections or tests necessary to verify conformance of products, items, processes, and computer programs, or to demonstrate satisfactory performance of service received.

We shall specify or conduct inspections and acceptance tests on those products, items, processes, and computer programs that are quality affecting or critical to the success of the process for which they will be used.

\subsubsection{Measurement and Inspection of Quality Characteristics}

We shall specify the quality characteristics to be measured, inspected or verified, and the methods that we shall use to conduct verification when we write procurement documents and standard operating procedures,

Characteristics selected shall be quality affecting. The type and extent of testing/inspection shall depend on the type of process, product or service, and on the record of a supplier's previously demonstrated performance.

\subsubsection{Documents and Records}

We shall prepare and maintain records of our inspections and tests that document the conformance of items, processes, and products to specified requirements. 
HNF-SD-WM-QAPP-025

Revision 3

\subsubsection{Receiving Inspection}

Critical process items, products, and services that we receive shall be verified according to procurement documents and/or test inspection plans to ensure conformance to specified requirements. We shall not use or release critical incoming products or services until they have been verified as conforming with our requirements.

We shall segregate and hold critical incoming products that require inspection, laboratory or physical testing until those items meet acceptance requirements, or otherwise are dispositioned if found to be nonconforming. Materials pending inspection or acceptance testing shall be identified with "HOLD" tags, or other equivalent means.

\subsubsection{In-Process Measurement, Inspection and Verification}

The TWRS Characterization Project plant operating or standard operating procedures, or work instructions, shall specify any quality characteristics to be measured, inspected or verified during the collection of tank waste samples in-situ or laboratory measurements.

These procedures and instructions shall identify any mandatory hold points requiring verification of quality characteristics of an item or process.

Laboratories that characterize waste tank samples shall perform in-process verification of quality characteristics through self review, peer review, and supervisory review of measurement processes and completed data. The objective is to assure conformance with analytical process quality control and Data Quality Objective requirements. The review process shall be documented. Data shall not be released to Characterization Project personnel until verification of data is complete.

\subsubsection{Training and Qualification Requirements}

We shall use trained and qualified personnel to conduct verification, inspection and acceptance testing. These people shall have the freedom and responsibility to report nonconforming items, services, products and out-of-control processes.

\subsubsection{Nonconforming Products and Services}

We shall identify, as appropriate, rejected products and services with a "REJECT" tag or other equivalent means. Disposition of nonconforming product and services is described in QP 3.0, Section 3.2.1, "Control of Nonconforming Items, Services, Processes and Products".

Products and affected items shall be marked or otherwise identified, or segregated, to prevent their inadvertent use before disposition of incorrect or defective products and services. 


\subsubsection{Final Inspection}

We shall conduct final verifications and inspections of our completed products and services according to procedures to ensure conformance to specified requirements.

All Characterization Project employees are responsible for verifying that their final work process output conforms to specified requirements.

Those having final responsibility for a system, structure, or component shall verify that systems, structures, or components conform to specified requirements.

\subsubsection{Inspection and Testing Equipment}

We shall calibrate and maintain equipment that we use to conduct tests or inspections to determine acceptance of items, processes, or products.

Our quality requirements for measuring and test equipment used for inspection and acceptance testing are not different for similar equipment used for controlling work processes. These requirements are specified in QP 5.0, "Work Process Control," Section 5.2.5, "Calibration and Maintenance of Equipment."

\subsection{REQUIREMENTS AND RESPONSIBILITIES}

\subsubsection{Characterization Project Managers}

Characterization Project managers:

- Determine appropriate verification or inspection points; establish what will be inspected and commensurate acceptance criteria.

- Develop, prepare, implement, and maintain quality assurance project plans or procedures that describe in-process and final inspection, verification, and test procedures.

- Ensure that no data, information, or report is released until final inspection and verification demonstrate product conformance to specified requirements, and that all associated data and documents that confirm conformance to requirements are available and authorized. 
HNF-SD-WM-QAPP-025

Revision 3

\title{
TANK WASTE REMEDIATION SYSTEM CHARACTERIZATION PROJECT QUALITY POLICIES
}

\author{
QUALITY POLICY 9.0
}

\section{MANAGEMENT ASSESSMENTS}

\subsection{PURPOSE AND SCOPE}

Establish the Characterization Project's policy, requirements, and responsibilities to conduct management assessments.

\subsection{POLICY}

\subsubsection{Management Assessment}

Management assessments evaluate Characterization Project's organization to determine, among other things, the effectiveness of management's quality system. Assessments are conducted by, or authorized by, Characterization Project Management. Management's objective is to learn how well the quality system and other management systems are working in order to take action to improve systems and quality.

\subsubsection{Performing Organization}

All levels of Characterization Project management shall periodically assess the organization for which they are responsible. Characterization Project senior managers shall retain overall responsibility for management self-assessments, whether conducted by themselves, or assigned to others. Managers at all levels shall participate in assessments.

Acting on behalf of management, assigned personnel of the Quality Assurance (QA) organization shall participate with, or plan and conduct assessments for, Characterization Project management to:

- Monitor work processes to determine if the customer's requirements are being achieved

- Evaluate Characterization Project products to determine if they conform to specified requirements

- Identify abnormal performance and potential problems

- Identify opportunities, areas, and processes that can be improved. 


\subsubsection{Assessment Personnel}

Personnel who conduct assessments:

- $\quad$ shall not be directly responsible for the work processes and systems which they assess.

- $\quad$ shall be qualified and technically knowledgeable in the subject matter assessed.

- shall have sufficient authority and freedom from line organization to carry out their responsibilities.

- shall focus on results and quality improvement.

\subsubsection{Assessment Performance}

We shall conduct assessments which are planned, scheduled, and documented according to established procedures and checklists.

We shall schedule assessments depending on how important the process is to the success of the Characteristic Project. Those processes or areas that have been problematic shall receive increased assessments.

We shall conduct assessments to determine the effectiveness of the quality system and to verify conformance of the activities with implementation plans, procedures, specifications and requirements.

We shall evaluate elements of the quality system against specified requirements. We shall examine objective evidence to verify that quality requirements are being implemented.

\subsubsection{Assessment Results and Reports}

The outcome of management self-assessments shall be documented and reported to appropriate levels of Characterization Project management and employees. Adequate information shall be documented so that meaningful action can be taken. Assessments and surveillance conducted by QA shall be documented and reported to QA management and to appropriate levels of Characterization Project management.

\subsection{REQUIREMENTS AND RESPONSIBILITIES}

\subsubsection{Characterization Project Directors and Managers}

Characterization Project directors and managers shall:

- Retain overall responsibility for management assessments 
HNF-SD-WM-QAPP-025

Revision 3

- Annually review and document the overall effectiveness of the Characterization Project Quality Management System and Quality Policies

- For the area managed, conduct and document management assessments. Identify and document performance problems and conditions adverse to quality. Identify opportunities for quality improvement

- Take prompt action to correct problems, deficiencies, and improve processes, quality and management systems

- Conduct follow-up evaluations of actions taken to determine the effectiveness of the respective action

\subsubsection{Characterization Project Quality Assurance Lead}

The QA Lead shall:

- Assist in Characterization Project assessments, as necessary

- Maintain records of assessments conducted by Characterization Project quality representatives

- Schedule and perform assessments on the basis of status of the activity and its importance to the success of the Characterization Project

- Communicate the results of assessments to appropriate management using a written and signed report

- Evaluate the adequacy of management responses to assessment deficiencies and conduct follow-up evaluations to verify that corrective actions have been accomplished, as scheduled

- Maintain records of assessment plans, reports, written replies, and records of corrective action completion conducted by Characterization Project quality representatives. 
HNF-SD-WM-QAPP-025

Revision 3

TANK WASTE REMEDIATION SYSTEM

CHARACTERIZATION PROJECT QUALITY POLICIES

\author{
QUALITY POLICY 10.0
}

\title{
INDEPENDENT ASSESSMENT
}

\subsection{PURPOSE AND SCOPE}

Establish the Characterization Project's policy for independent assessments.

\subsection{POLICY}

\subsubsection{Assessment Initiated by External Organizations}

Independent assessments may be conducted by the Fluor Daniels Hanford, Facility Evaluation Board (FEB) from time to time. The FEB provides senior management with information needed to measure a facility's effectiveness and assure adherence to applicable conduct-ofoperations, environmental, safety, health, and quality assurance requirements.

Scheduling of independent assessments will be coordinated between the Characterization Project and the external organization.

\subsubsection{Assessment Initiated by Characterization Project}

Independent assessments are a management tool to advise and inform Characterization Project management of the implementation and adequacy of its quality systems. They may be initiated by Characterization Project management to determine if planned quality systems are implemented and if those systems are producing processes, products, and services which meet or exceed the customer's requirements.

Personnel selected to perform "independent assessments" shall be qualified and knowledgeable in the subject matter assessed. These personnel will not be directly responsible for the work processes and systems which they assess.

\subsubsection{Assessment Results and Reports}

The documented results of independent assessments shall be carefully considered by Characterization Project management. The proper response to any findings of an independent assessment team will be developed. 
Accepted deficiencies within the operations of the Characterizaton Project will be corrected and reported to the assessment team through the assigned corrective actions Point of Contact (POC) to assure closure on open findings.

\section{3 REQUIREMENTS AND RESPONSIBILITIES}

\subsubsection{Characterization Project Directors and Managers}

Characterization Project management shall:

- Review the assessment reports and develop an appropriate response commensurate with the importance and severity of the identified problems.

- Investigate adverse findings; develop and take timely, effective corrective action.

- Track and verify the adequacy of implemented corrective action. 
HNF-SD-WM-QAPP-025

Revision 3

TANK WASTE REMEDIATION SYSTEM CHARACTERIZATION PROJECT QUALITY POLICIES

\author{
QUALITY POLICY 11.0
}

\title{
DATA AND INFORMATION MANAGEMENT
}

\subsection{PURPOSE AND SCOPE}

Establish the Characterization Project's policy, requirements, and responsibilities to manage data and information.

\subsection{POLICY}

The Tank Characterization Data Management System shall provide data and information of known and acceptable quality when needed, in the form needed and at a reasonable cost. These requirements are implemented by policies pertaining to data collection, data maintenance and data dissemination.

\subsubsection{Data Collection Policy}

Data shall be captured once at the source and in a standard electronic form receivable by official TWRS databases including specifically: The Tank Characterization Database (TCD), the Surveillance Analysis Computer System (SACS), and the Tank Vapor Database (TVD). Data shall be transmitted in electronic form to eliminate human manipulation, multiple entry, and sources of error, and limit use of hard copies.

\subsubsection{Data Maintenance Policy}

Databases and data sources shall be managed to provide; safe/secure storage of data, access control to avoid loss or corruption of data, change control to ensure changes are reviewed and approved prior to implementation, archive and back-up capabilities to optimize storage space, and to protect data from loss. Databases and data sources shall be registered in the TWRS Information Locator Database (TILD) and the Hanford Information Systems Inventory (HISI).

Databases and data sources shall be self-assessed at least annually for compliance with minimum standards of hardware, software, and data administration. DI-DM-002.00, SelfAssessment Standards Checklist for Data Systems, or equivalent, may be used for this purpose.

\subsubsection{Data Dissemination Policy}

New databases and data sources shall be designed consistent with a Hanford standard architecture to assure that databases and data sources are accessible via the Hanford Local Area 
Network (HLAN) or by external or internal World Wide Web (WWW) Hanford home page as appropriate. Existing databases and data sources shall be electronically linked via the HLAN or WWW to the extent practicable.

\subsubsection{Hard Copy and Electronic Document Policy}

Documents prepared by and for the Characterization Project shall conform to standards for hard copy and electronic information deliverables (see WHC-SD-WM-MP-002, Rev. 0, attachment D).

\subsection{REQUIREMENTS AND RESPONSIBILITIES}

\subsubsection{Characterization Project Managers}

Characterization Project managers shall support the data and information management policies for electronic data collection, data maintenance, and data dissemination consistent with a architecture that provides electronic linkage and access to databases, data, and information sources.

\subsubsection{Technical Lead for Characterization Project Data Management}

The technical lead for Characterization Project data management shall provide technical assistance and leadership to implement the policies relating to data and information management for the Characterization Project; provide self-assessment services to the key Characterization Project databases and data sources; and maintain and enhance the TCD and Tank Characterization Resource Center. 
HNF-SD-WM-QAPP-025

Revision 3

\section{REFERENCES}

10 CFR 830.120, "Quality Assurance Requirements," Code of Federal Regulations, as amended (59 FR 15843, 15852).

ANSI/ASQC, 1994, Quality Assurance Program Requirements for Environmental Programs, ANSI/ASQC E4-1994, American Society for Quality Control, Energy Division, Environmental Waste management Committee.

Ecology, EPA, and DOE, 1994, Hanford Federal Facility Agreement and Consent Order, as amended, Washington State Department of Ecology, U.S. Environmental Protection Agency, and U.S. Department of Energy, Olympia, Washington.

EPA, September 20, 1980, Guidelines and Specifications for Preparing Quality Assurance Program Plans, QAMS-004/80, U.S. Environmental Protection Agency, Washington, D.C.

EPA, December 29, 1980, Interim Guidelines and Specifications for Preparing Quality Assurance Project Plans, QAMS-005/80, U.S. Environmental Protection Agency, Washington, D.C.

EPA, January 1994, EPA Requirements for Quality Assurance Project Plans for Environmental Data Operations, EPA QA/R-5, U.S. Environmental Protection Agency, Washington, D.C.

EPA, 1994, Guidance for Planning Data Collection in Support of Environmental Decision Making Using the Data Quality Objective Process, EPA QA/G-4, U.S. Environmental Protection Agency, Washington, D.C.

DOE/RL, 1994, Hanford Analytical Services Quality Assurance Plan, DOE/RL-94-55, Rev. 1, U.S. Department of Energy, Richland Operations Office, Richland, Washington.

WHC-CM-4-2, Quality Assurance Manual, Westinghouse Hanford Company, Richland, Washington.

WHC-CM-6-1, Standard Engineering Practices, Westinghouse Hanford Company, Richland, Washington.

WHC-CM-6-34, TWRS Quality Assurance Plan, Westinghouse Hanford Company, Richland, Washington.

WHC-EP-0732, TWRS Data Quality Objective Strategy, Westinghouse Hanford Company, Richland, Washington. 
HNF-SD-WM-QAPP-025

Revision 3

\section{REFERENCES (continued)}

HNF-SD-WM-QAPP-0035, Rev 0, Work Process Improvement and Quality Management System Plan.

WHC-SD-WM-MP-002, Rev. 0, Tank Characterization Project, Data Management Plan, Westinghouse Hanford Company, Richland, Washington.

HNF-SD-WM-QAPP-013, Rev. 3 Quality Assurance Project Plan for Sampling and Analysis of Waste Tank Headspace Vapors, Westinghouse Hanford Company, Washington.

WHC-SD-WM-TA-163, Tank Waste Characterization Process, Westinghouse Hanford Company, Richland, Washington.

WHC-SD-WM-TA-164, Tank Waste Characterization Basis, Westinghouse Hanford Company, Richland, Washington.

WHC-SP-1131, QA Program and Implementation Plan, Westinghouse Hanford Company, Richland, Washington. 
Revision 3

\section{GLOSSARY}

\section{ABBREVIATIONS AND ACRONYMS}

COE

CPO

DQO

DST

EPA

FEB

HISI

HLAN

OQS

POP

QA

QAP

QAPI

QP

SACS

SAP

SOP

SST

TCD

TCP

TCR

TILD

TSAP

TVD

TWRS

WWW center of expertise

Characterization Project Operations

data quality objective

double-shell tank

U.S. Environmental Protection Agency

Facilities Evaluation Board

Hanford information systems inventory

Hanford local area network

office of quality systems

plant operating procedure

quality assurance

quality assurance plan

quality assurance program index

quality policies

surveillance analysis computer system

sampling and analysis plan

standard operating procedure

single-shell tank

tank characterization database

tank characterization plan

tank characterization report

TWRS information locator database

tank sampling and analysis plan

tank vapor database

Tank Waste Remediation System

world wide web 
HNF-SD-WM-QAPP-025

Revision 3

This page intentionally left blank. 
HNF-SD-WM-QAPP-025

Revision 3

APPENDIX A

\section{QUALITY ASSURANCE PROGRAM INDEX}

A-1 
HNF-SD-WM-QAPP-025

Revision 3

Table 1-2. Characterization Project Quality Assurance Program Index

\begin{tabular}{|c|c|c|c|c|}
\hline 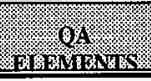 & 10\% & $\mathrm{BaM}=4$ & WNGSD & 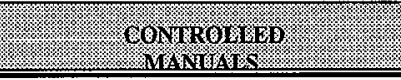 \\
\hline $\begin{array}{l}\text { Quality } \\
\text { Assurance } \\
\text { Program }\end{array}$ & 1 (I) & $\begin{array}{l}\text { QR } 1.0 \\
\text { QR } 2.0\end{array}$ & QP 1.0 & $\begin{array}{l}\text { CM-1, Company Policies \& Charters } \\
\text { CM-1-3, Management Requirements \& } \\
\text { Procedures } \\
\text { CM-5-4, Laboratories Administration } \\
\text { CM-6-1, Standard Engineering Practices } \\
\text { CM-6-2, Project Management }\end{array}$ \\
\hline $\begin{array}{l}\text { Personnel } \\
\text { Training } \\
\text { and } \\
\text { Qualification }\end{array}$ & 1 (ii) & $\begin{array}{l}\text { QR 2.0 } \\
\text { QR 9.0 } \\
\text { QR } 10.0\end{array}$ & QP 2.0 & $\begin{array}{l}\text { CM-1-4, Corrective Action Management } \\
\text { Manual } \\
\text { CM-2-15, Training Standards } \\
\text { CM-4-5, Quality Assurance } \\
\text { Qualifications \& Instructions } \\
\text { CM-4-39, Qualification \& Certification } \\
\text { of Nondestructive Examination Personnel } \\
\text { CM-5-4, Laboratories Administration } \\
\text { CM-7-5, Environmental Compliance }\end{array}$ \\
\hline $\begin{array}{l}\text { Quality } \\
\text { Improvement }\end{array}$ & 1 (iii) & $\begin{array}{l}\text { QR 15.0 } \\
\text { QR 16.0 }\end{array}$ & QP 3.0 & $\begin{array}{l}\text { CM-1-4, Corrective Action Management } \\
\text { Manual } \\
\text { CM-5-4, Laboratories Administration }\end{array}$ \\
\hline $\begin{array}{l}\text { Documents } \\
\text { and } \\
\text { Records }\end{array}$ & 1(iv) & $\begin{array}{l}\text { QR 4.0 } \\
\text { QR } 6.0 \\
\text { QR } 17.0\end{array}$ & QP 4.0 & $\begin{array}{l}\text { CM-1-3, Management Requirements \& } \\
\text { Procedures } \\
\text { CM-3-5, Document Control \& Record } \\
\text { Management Manual } \\
\text { CM-5-4, Laboratories Administration } \\
\text { CM-6-1, Standard Engineering Practices }\end{array}$ \\
\hline $\begin{array}{l}\text { Work } \\
\text { Processes }\end{array}$ & 2 (d) & $\begin{array}{l}\text { QR 5.0 } \\
\text { QR 8.0 } \\
\text { QR 9.0 } \\
\text { QR 11.0 } \\
\text { QR 12.0 } \\
\text { QR 13.0 } \\
\text { QR 14.0 }\end{array}$ & QP 5.0 & $\begin{array}{l}\text { CM-1-3, Management Requirements \& } \\
\text { Procedures } \\
\text { CM-1-5, Standard Operating Practices } \\
\text { CM-3-5, Document Control \& Record } \\
\text { Management Manual } \\
\text { CM-5-3, Sample Management \& } \\
\text { Administration } \\
\text { CM-5-4, Laboratories Administration } \\
\text { CM-6-1, Standard Engineering Practices } \\
\text { CM-6-2, Project Management }\end{array}$ \\
\hline Design & 2 (ii) & QR 3.0 & QP 6.0 & $\begin{array}{l}\text { CM-1-3, Management Requirements \& } \\
\text { Procedures } \\
\text { CM-3-5, Document Control \& Record } \\
\text { Management Manual } \\
\text { CM-3-10, Software Practices } \\
\text { CM-6-1, Standard Engineering Practices } \\
\text { CM-6-2, Project Management } \\
\text { AC-IP-1026, Engineering Practice } \\
\text { Guidelines }\end{array}$ \\
\hline
\end{tabular}




\section{HNF-SD-WM-QAPP-025}

Revision 3

\begin{tabular}{|c|c|c|c|c|}
\hline 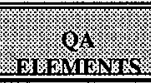 & 10\% rar & $\sin _{4}$ & 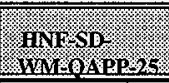 & 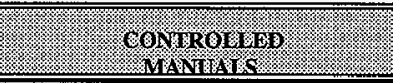 \\
\hline Procurement & 2 (iii) & $\begin{array}{l}\text { QR } 4.0 \\
\text { QR } 7.0\end{array}$ & QP 7.0 & $\begin{array}{l}\text { CM-1-3, Management Requirements \& } \\
\text { Procedures } \\
\text { CM-2-1, Procurement Manual \& } \\
\text { Procedures } \\
\text { CM-2-2, Materials Management Manual } \\
\text { CM-5-4, Laboratories Administration } \\
\text { CM-6-1, Standard Engineering Practices } \\
\text { CM-6-2, Project Management }\end{array}$ \\
\hline $\begin{array}{l}\text { Inspection } \\
\text { and Testing }\end{array}$ & 2 (iv) & $\begin{array}{l}\text { QR } 10.0 \\
\text { QR } 11.0 \\
\text { QR 14.0 }\end{array}$ & QP 8.0 & $\begin{array}{l}\text { CM-1-3, Management Requirements \& } \\
\text { Procedures } \\
\text { CM-2-1, Procurement Manual \& } \\
\text { Procedures } \\
\text { CM-5-4, Laboratories Administration } \\
\text { CM-6-1, Standard Engineering Practices } \\
\text { CM-6-2, Project Management }\end{array}$ \\
\hline $\begin{array}{l}\text { Management } \\
\text { Assessments }\end{array}$ & 3 (I) & $\begin{array}{l}\text { QR } 16.0 \\
\text { QI } 16.3\end{array}$ & QP 9.0 & $\begin{array}{l}\text { CM-4-2, Quality Assurance Manual } \\
\text { CM-5-4, Laboratories Administration }\end{array}$ \\
\hline $\begin{array}{l}\text { Independent } \\
\text { Assessments }\end{array}$ & 3 (ii) & QR 18.0 & QP 10.0 & $\begin{array}{l}\text { CM-4-2, Quality Assurance Manual } \\
\text { CM-5-4, Laboratories Administration }\end{array}$ \\
\hline
\end{tabular}

